\title{
Potential Energy Recovery Using Micro-Hydropower Technology in Irrigation Networks: Real-World Case Studies in the South of Spain ${ }^{+}$
}

\author{
Miguel Crespo Chacón ${ }^{1}$, Juan Antonio Rodríguez-Díaz 2, Jorge García Morillo 2, John Gallagher ${ }^{1}$, \\ Paul Coughlan ${ }^{3}$ and Aonghus McNabola 1,* \\ 1 Department of Civil, Structural and Environmental Engineering, Trinity College Dublin, D02 PN40 Dublin, \\ Ireland; crespocm@tcd.ie (M.C.C.); j.gallagher@tcd.ie (J.G.) \\ 2 Department of Agronomy, University of Córdoba, International Campus of Excellence ceiA3, \\ 14071 Córdoba, Spain; jarodriguez@uco.es (J.A.R.-D.); g62gamoj@uco.es (J.G.M.) \\ 3 Trinity Business School, Trinity College Dublin, D02 PN40 Dublin, Ireland; coughlnp@tcd.ie \\ * Correspondence: amcnabol@tcd.ie; Tel.: +353-1896-3837 \\ + Presented at the 3rd EWaS International Conference on "Insights on the Water-Energy-Food Nexus", \\ Lefkada Island, Greece, 27-30 June 2018.
}

Published: 1 August 2018

\begin{abstract}
The agricultural sector is one of the most significant users of water resources worldwide. Irrigation infrastructure has been modernized in recent years in many regions dedicated to agriculture, transitioning from traditional open channels to more efficient on-demand pressurized irrigation networks. Despite improvements in water efficiency, the modernization of these networks has led to increased energy demands of the irrigation sector. Several negative consequences have been linked to additional energy requirements of pressurized networks, such as the rising cost of irrigation water. Other consequence linked has been the excess pressure in certain locations that could be used to recover energy from these networks. This paper studies the excess pressure in pressurized irrigation networks and the conversion of this excess to usable energy by means of small-scale hydropower turbines. Twelve irrigation networks located in the South of Spain have been modelled, quantifying the excess pressure available for power generation. Over $1 \mathrm{GWh}$ per annum has been estimated that could be recovered.
\end{abstract}

Keywords: hydropower; irrigation networks; excess pressure; turbines; energy recovery

\section{Introduction}

Globally, agriculture tends to be the main water consumer, reaching values of around $70 \%$ of all water use worldwide, and close to $95 \%$ in some developing countries [1]. Water scarcity is prevalent in many areas around the world where agriculture is the main economic activity. Thus, a $60 \%$ increase in the demand for food by 2050, which will result in a further requirement of $14 \%$ more water for irrigated agriculture [2]. Therefore, improving the water use efficiency has become a primary concern in the sector nowadays.

Modernization aims to improve the water-use efficiency through the pressurization of the water distribution networks. However, these upgrades have meant an increase in energy demands. This process can be observed in several European countries [3], such as Spain, where surface irrigation has shifted from $80 \%$ of irrigation land in 1980 to $25 \%$ in 2017 [4]. In contrast to this improvement in the water-use efficiency, the energy demand linked to irrigation has been greatly increased [5]. Therefore, the profits and the viability of farms have been reduced in recent years due to higher consumption of energy and the rising cost of energy tariffs [6]. Previous investigations in Spain 
highlighted that, on average, a pressurized irrigation network requires $2 \mathrm{~kW} \mathrm{ha}^{-1}$ and annually between 600 and $1600 \mathrm{kWh} \mathrm{ha}^{-1}[7,8]$. Thus, management, operation and maintenance (MOM) costs have increased fivefold: from $€ 0.02 \mathrm{~m}^{-3}$ with the traditional 'open channel' irrigation infrastructure by gravity, to $€ 0.10 \mathrm{~m}^{-3}$ after the modernization processes [9].

Several authors have highlighted the potential for energy recovery from urban water supply networks using the micro-hydropower (MHP) turbines at points of excess pressure. Recent research has studied the application of MHP turbines in water supply and wastewater infrastructure [10,11]. In water supply infrastructure, singular points, such as pressure reducing valves (PRVs), break pressure tanks (BPTs) and service reservoirs, have been shown to have potential for energy recovery. Ramos [12] found a potential site of $260 \mathrm{~kW}$ in a service reservoir, where $€ 113,800$ per annum could be produced using micro-hydropower turbines. Gallagher [13] highlighted the existence of 80 points in Ireland and Wales, where the potential energy recovery varied between 5 and $300 \mathrm{~kW}$, having the potential to generate $17.9 \mathrm{GWh}$ per annum. The use of pump-as-turbines (PATs) for both, energy recovery and pressure control, has been shown as a cost-effective device, potentially 10 percent of the cost of conventional MHP turbines [14,15] at sites with small power output capacity $[16,17]$.

In contrast to urban supply, there are very few works about potential MHP energy recovery in irrigation networks. Pérez Sánchez et al. [18] studied the case of a drip irrigation network located in Valencia (Spain), which covered 290.2 hectares, where the maximum energy potentially recovered was estimated up to 188.23 MWh per annum. In Córdoba (Spain), García Morillo et al. [19] noted that the use of MHP turbines and PATs could generate 309.7MWh per annum in an irrigated area of 4000 hectares.

This paper undertakes an analysis of the energy recovery potential in 12 irrigation networks in Bembezar MD irrigation district (BMD), using small-scale turbines and PATs. The efficiency has been considered variable for these turbines. Finally, this analysis allows for a spatial and temporal extrapolation of these potential resources across the EU and into the future.

\section{Study Area}

This study has been carried out in the left and right banks of the Bembezar river (BMI and BMD respectively) that are divided into 12 irrigation sectors located in Andalusia, South of Spain. Four of these networks are in Cordoba province, and eight in Seville.

The irrigated total area is approximately 16,000 hectares, and each sector is supplied by an independent pressurized on-demand water distribution network (water is continuously available to farmers). All the networks are designed to supply $1.2 \mathrm{~L} \mathrm{ha}^{-1} \mathrm{~s}^{-1}$ to the hydrants. In total, there were 1734 hydrants, whose elevations ranged from 28 m.O.D to 112 m.O.D. The minimum service pressures is $35 \mathrm{~m}$. The irrigation surface of each sector, their location, and the hydrants fed are shown in the Table 1. The main crops are citrus, maize, olive tree, sunflower and cotton. All of these sectors are irrigated by drip irrigation systems.

Table 1. Summary table of the irrigation sectors studied, presenting their location, the surface area irrigated and the number of hydrants that are fed by the networks district.

\begin{tabular}{ccc}
\hline Irrigation District & Surface (ha) & Hydrants \\
\hline BMI & 4000 & 28 \\
BMD S-III & 631 & 95 \\
BMD S-IV & 1679 & 159 \\
BMD S-V & 1186 & 81 \\
BMD S-VI1 & 726 & 89 \\
BMD S-VI2 & 924 & 156 \\
BMD S-VII & 922 & 162 \\
BMD S-VIII1 & 1141 & 142 \\
BMD S-VIII2 & 1686 & 196 \\
BMD S-IX & 1275 & 191 \\
BMD S-X & 993 & 296 \\
BMD S-XI & 836 & 139 \\
Total & $\mathbf{1 5 , 9 9 9}$ & $\mathbf{1 7 3 4}$ \\
\hline
\end{tabular}


The mean rainfall and evapotranspiration between 2010 and 2016 was measured at local weather stations and equaled $547 \mathrm{~mm}_{\text {year-1 }}$ and $1400 \mathrm{~mm}_{\text {year-1 }}{ }^{-1}$ respectively. This information is important since it will characterize the crop water requirements. Figure 1 shows a map with the location of the networks.

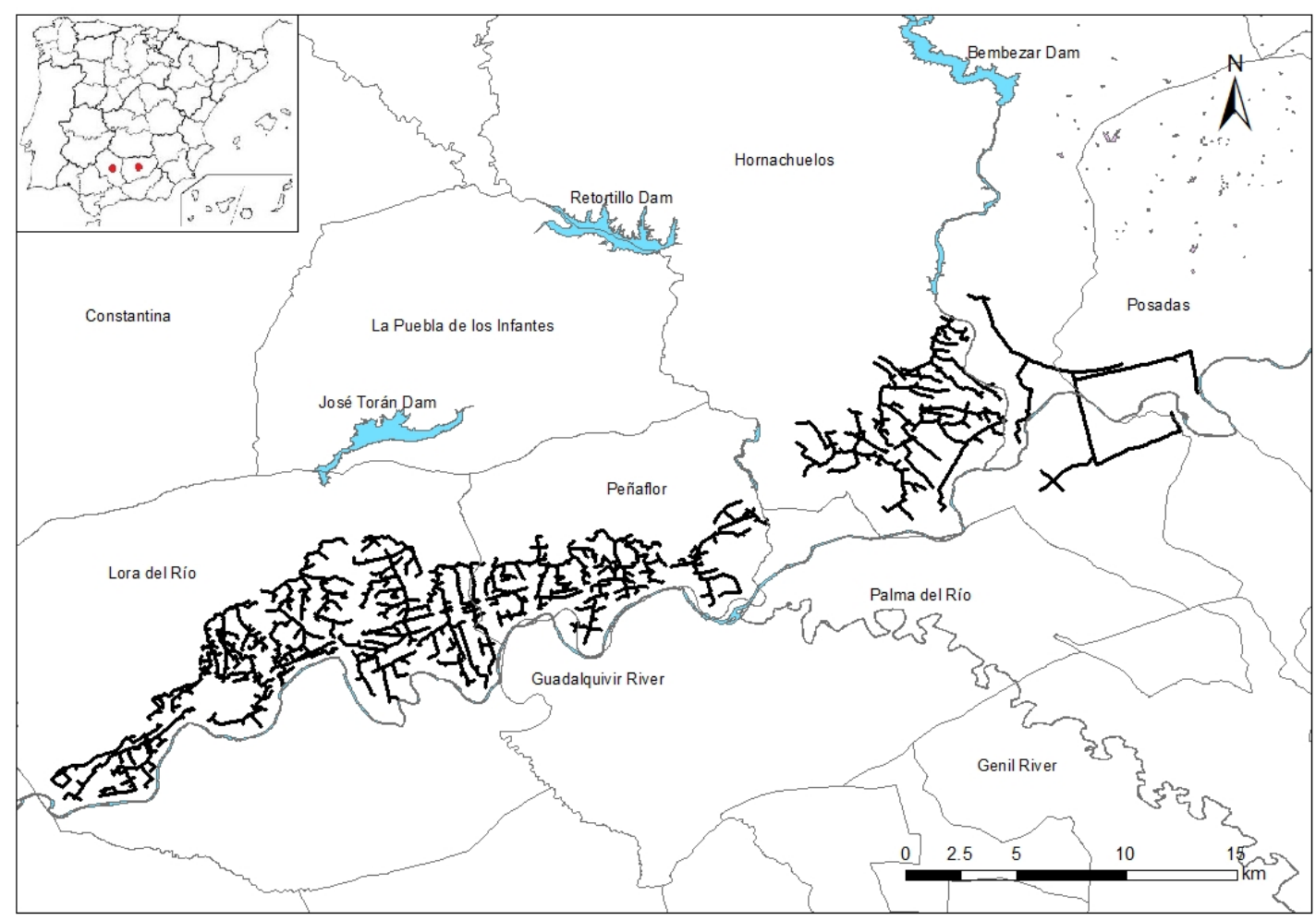

Figure 1. Location of BMI and BMD irrigation districts.

\section{Methodology}

The methodology proposed in the research is composed of three phases and has been applied in every network. Also, a feasibility assessment has been carried out at each proposed location of excess pressure for the installation of a MHP or PAT.

In the first phase, the network was modelled in the hydraulic simulator EPANET. Initially, all the networks were analyzed considering that all the hydrants were simultaneously open. Thus, through this first model, sites with excess pressure in periods of peak water demand were identified and potential energy recovery sites were located.

After the first hydraulic model, in the second phase, the irrigation requirements in all the networks were calculated according to their respective cropping patterns. Subsequently an evaluation of the probabilistic methods to size irrigation networks was conducted using the Clément's methodology [20]. Clément methodology comprises two stages. The first one is based on Bernoulli trials, which studies the behavior of each hydrant separately. Through this distribution two different results can be obtained: success or failure. Thus, applying the results to irrigation networks, hydrants can be open or closed. An open or closed hydrant can be represented through a Bernoulli trial with a probability of ' $p$ ' or ' $1-p$ ' respectively. The second stage studied the behaviour of the set of hydrants as a statistical sum of Bernoulli trials.

$$
\begin{gathered}
X=1 \text { (open hydrant) with a probability } p \\
X=0 \text { (closed hydrant) with a probability } 1-p
\end{gathered}
$$

The probability of a hydrant to be open is calculated through the quotient between the hours per day needed by the farmer to satisfy the crop water requirement $\left(t^{\prime}\right)$ and the water availability in hours 
per day $\left(\mathrm{t}^{\prime \prime}\right)$. Water was available for $24 \mathrm{~h}$ per day in all the networks studied, being on-demand irrigation networks (see Equation (1)).

$$
\mathrm{p}=\frac{\mathrm{t}^{\prime}}{\mathrm{t}^{\prime \prime}}
$$

The irrigation time required per crop is directly linked to the water volume needed, $I N_{i}$, which is calculated according to [21], and is inversely proportional to the design water supply, $\mathrm{q}_{\max }(1.2 \mathrm{~L}$ $\mathrm{s}^{-1} \mathrm{ha}^{-1}$ in this case). Thus, the irrigation time required for each crop depending on the volume of water is expressed as Equation (2).

$$
\mathrm{t}_{\mathrm{i}}^{\prime}=\frac{1}{3600} \frac{\mathrm{IN}_{\mathrm{i}}}{\mathrm{q}_{\max }}
$$

In the third phase, the energy production of a MHP or PAT is modelled for thousands of water demand patterns (combinations of open and closed hydrants). Hence, in these points mean values of flows and head-losses were obtained for each month, after 15,000 simulations in each network and month. This was conducted using the mathematical programming language MATLAB, integrating the EPANET engine thorough its dynamic link library. After this, a quantification of the energy available in every location identified for energy recovery was estimated. The power available at each potential location was determined according to Equation (3), using the flows and head-losses obtained in the previous step.

$$
\mathrm{P}=\gamma_{\mathrm{w}} \mathrm{QH} \eta
$$

where $\gamma_{\mathrm{w}}$ is the specific weight of the water $\left(9.81 \mathrm{kN} \mathrm{m}^{-3}\right), \mathrm{Q}$ is the flow passing through the turbine $\left(\mathrm{m}^{3} \mathrm{~s}^{-1}\right), \mathrm{H}$ the pressure $(\mathrm{m})$ and $\eta$ the turbine efficiency.

In order to account for the variation of flow on turbine efficiency, particularly for PAT cases, the equation proposed by Novara [22], which is currently under development, has been used. According to this, the efficiency in each month and the power generation, fixing a maximum of the efficiency of $60 \%$, to keep in mind the concept of hydraulic regulation for managing the pressure [23], and decreasing this for other flow values. The energy production was modelled for the peak irrigation season, from May to September.

\section{Results and Discussion}

The results for the assessment presented a total of 43 location for energy recovery, from the 12 irrigation networks, as suitable locations for the installation of MHP turbines or PATs (Table 2). This potential translated as in excess of $1 \mathrm{MW}$, being capable of generating over $1 \mathrm{GWh}$ per annum. Figure 2 presents a supporting map generated of the gradient for energy available in the 12 irrigation networks, to visualise the potential energy that could be recovered from irrigation networks by the use of MHP technology (in kWh).

Analyzing the networks, there is a minimum of two energy recovery locations in almost each district, with the exception of Sector XI where there was no potential for power generation. The left bank of the Bembezar river irrigation district (BMI) provided more opportunities for energy recovery, with five potential sites with a range power of $15 \mathrm{~kW}$ and $112 \mathrm{~kW}$. Considering the whole set of networks, the lowest potential power generation found has been of $5 \mathrm{~kW}$ in the Sector IV of the right bank of the Bembezar River (BMD S-IV) and the highest potential $112 \mathrm{~kW}$ in the BMI, with a potential energy recovery of $114 \mathrm{MWh}$, equating to approximately $45 \%$ of the total potential for energy recovery in the BMI irrigation district and $11 \%$ of the energy available in the whole set of networks.

BMI was the district with a higher potential for energy recovery a 255 MWh annually. Nonetheless, the BMI irrigation district is the biggest network which covers 4000 hectares, $25 \%$ of the total irrigated area. However, analysing the power generation per unit area $\left(\mathrm{kW} \mathrm{ha}^{-1}\right)$ and the energy recovery per unit area ( $\left.\mathrm{kWh} \mathrm{ha}^{-1}\right)$, Sector VI.1 of the right bank of the Bembezar River (BMD S-VI.1) had greater possibilities with $0.15 \mathrm{~kW} \mathrm{ha}^{-1}$ and $171.9 \mathrm{kWh} \mathrm{ha}^{-1}$. 
Table 2. Summary table of the results obtained for each irrigation network. Potential points where turbines could be installed, potential power, energy that could be recovered per annum and the parameters power available per surface unit $\left(\mathrm{kW} \mathrm{ha}^{-1}\right)$ and energy that could be recovered per surface unit (kWh ha-1).

\begin{tabular}{cccccc}
\hline $\begin{array}{c}\text { Irrigation } \\
\text { District }\end{array}$ & $\begin{array}{c}\text { Potential } \\
\text { Sites }\end{array}$ & $\begin{array}{c}\text { Power } \\
\mathbf{( k W )}\end{array}$ & $\begin{array}{c}\text { Energy } \\
\mathbf{( M W h )}\end{array}$ & $\begin{array}{c}\text { Power/Surface } \\
\mathbf{( k W / h a )}\end{array}$ & $\begin{array}{c}\text { Energy/Surface } \\
\mathbf{( k W h / h a )}\end{array}$ \\
BMI & 5 & 261.5 & 255.04 & 0.07 & 63.8 \\
BMD S-III & 3 & 27.9 & 30.33 & 0.04 & 48.1 \\
BMD S-IV & 5 & 86.0 & 90.45 & 0.05 & 53.9 \\
BMD S-V & 2 & 50.0 & 45.56 & 0.04 & 38.4 \\
BMD S-VI.1 & 2 & 112.0 & 124.82 & 0.15 & 171.9 \\
BMD S-VI.2 & 3 & 78.5 & 82.94 & 0.08 & 89.8 \\
BMD S-VII & 3 & 45.0 & 47.57 & 0.05 & 51.6 \\
BMD S-VIII.1 & 4 & 96.2 & 103.93 & 0.08 & 91.1 \\
BMD S-VIII.2 & 7 & 104.7 & 111.97 & 0.06 & 66.4 \\
BMD S-IX & 5 & 72.5 & 78.88 & 0.06 & 61.9 \\
BMD S-X & 4 & 74.5 & 80.12 & 0.07 & 80.7 \\
BMD S-XI & 0 & 0 & 0 & 0 & 0 \\
Total & $\mathbf{4 3}$ & $\mathbf{1 0 0 8 . 8}$ & $\mathbf{1 0 5 1 . 6 1}$ & - & - \\
\hline
\end{tabular}

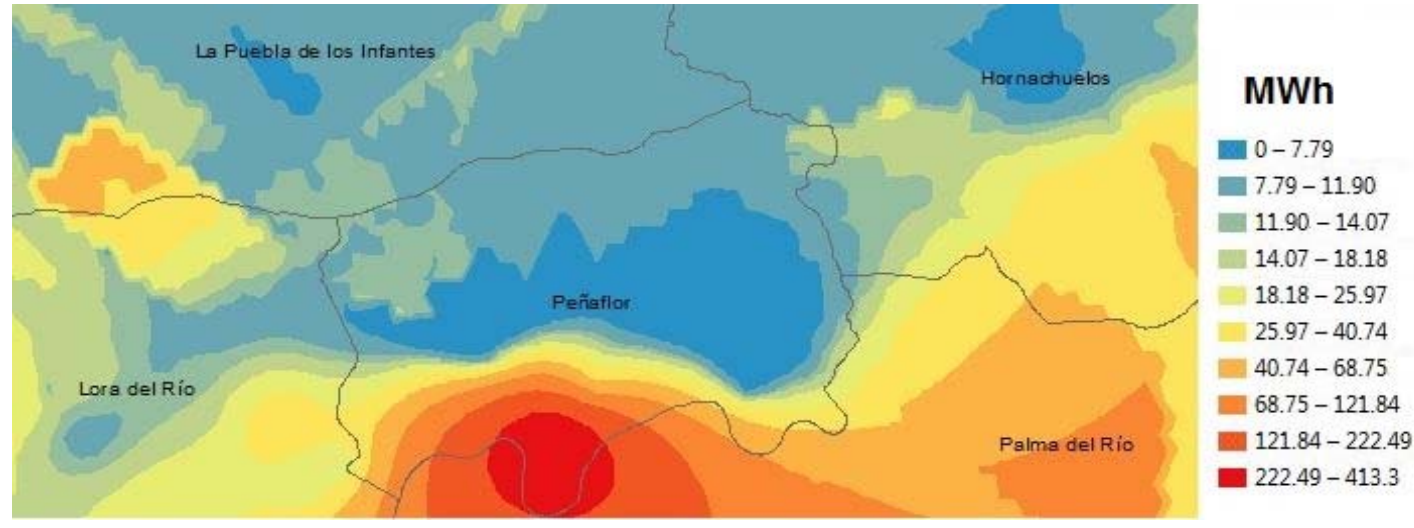

Figure 2. Gradient map of the potential energy that could be recovered, in $\mathrm{kWh}$, using MHP turbines and/or PATs in the 12 irrigation networks studied, generated using Kriging interpolation method.

Figure 3 presents the monthly distribution of the energy recovery potential at the 43 locations, with most of the energy is concentrated in the summer months (from June to September). More specifically, as mean value of the 43 potential points found, $34.5 \%$ of the energy would be recovered in June, $41.2 \%$ in July and $21.8 \%$ in August, resulting in $97.5 \%$ of the total amount. This happens since the irrigation season lasts between four and eight months, depending on the crop, and most of the water is required in these high temperature months (reaching more than $40{ }^{\circ} \mathrm{C}$ ). Thus, evapotranspiration and therefore crops water requirements are much higher and the irrigation activity is more focused in this time range.

In contrast, the water volume required in the rest of the months varies between $9.5 \%$ and $29.5 \%$, depending on the crop: Hence, the average potential for energy recovery in the other months within the irrigation season is $2.5 \%$. The reasons why the energy recovery percentage decreases at other times of the year is due to the variations of the flow affecting turbine efficiency, particularly when the device proposed is a PAT. Variation of $-20 \%$ of the flow in the PATs resulted in efficiency reductions of up to 70\% [24]. Also, the open hydrant hours were much higher in the summer months, resulting in a higher potential for energy recovery.

In comparison to previous investigations of MHP energy recovery in Spain over smaller irrigated areas, the mean energy recoverable in MWh year-1 ha-1 found by Pérez Sánchez et al. [18] and García Morillo et al. [19] were, 0.65 $\mathrm{MWh}_{\text {year-1 }} \mathrm{ha}^{-1}$ and $0.08 \mathrm{MWh}_{\text {year-1 }} \mathrm{ha}^{-1}$, respectively. In 
this study a rate of $0.07 \mathrm{MWh}$ year-1 $\mathrm{ha}^{-1}$ was estimated over a much larger area. Ultimately the amount of energy recoverable from pressurized irrigation networks is heavily dependent on elevation changes in the topography of the networks. The wider potential of this energy saving concept in Spain or the EU may be over-estimated by assessments of the potential which only include relatively small land area.

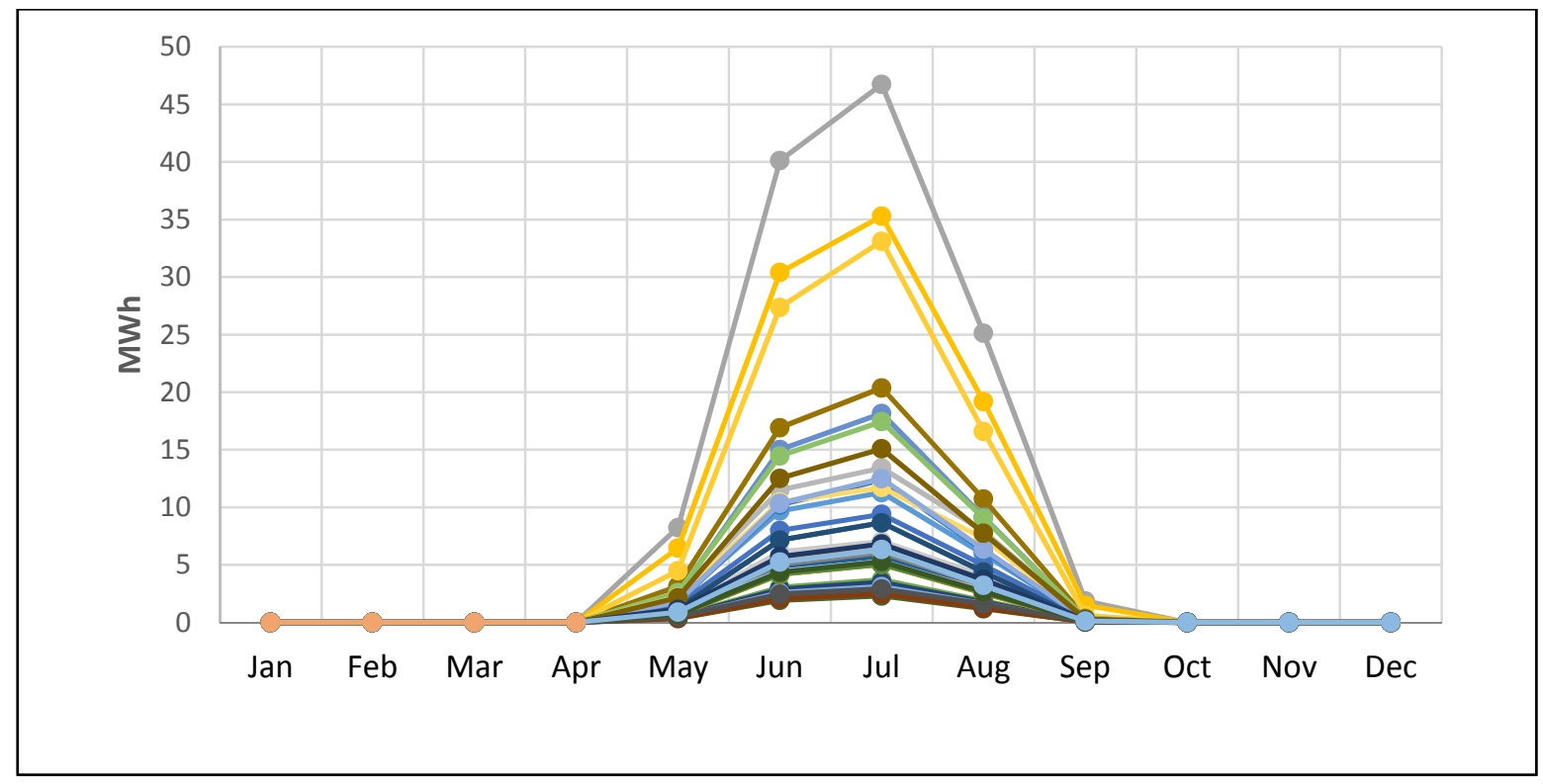

Figure 3. Monthly potential energy production, in $\mathrm{kWh}$, of the 43 potential points found, distributed my month.

\section{Conclusions}

The modernization of irrigation networks in the agricultural sector has led to an increase in energy consumption. This research highlights the potential for MHP generation in the pressurized irrigation networks. It has also assessed the possibility of using MHP turbines or PATs for energy recovery, since excess pressure has been quantified in almost all pressurized irrigation networks examined. Several determinants can explain the presence of this excess pressure such as the difference of hydrants elevation or the long distances that water needs to travel to reach the issuing hydrant. Although the irrigation season is concentrated in a few months during the year, depending on the crops in the area studied, most of the potential energy recovery is focused in the summer months.

Author Contributions: All the authors have participated in any step of this research. The author J.G. has contributed providing information about the turbines used in other studies. P.C. has supervised the development of the document. J.A.R.-D. and J.G.M. have provided information about the irrigation networks and supervised the hydraulic analysis. M.C.C. proposed the methodology to study the potential energy available in the networks and developed the calculations. A.M. has supervised every stage of the research.

Acknowledgments: This research is part funded by the European Regional Development Fund (ERDF) through the Interreg Atlantic Area Programme 2014-2020, as part of the REDAWN project (Reducing the Energy Dependency in the Atlantic Area from Water Networks).

Conflicts of Interest: The authors declare no conflict of interest. The founding sponsors had no role in the design of the study; in the collection, analyses, or interpretation of data; in the writing of the manuscript, and in the decision to publish the results. 


\section{References}

1. FAO. 2050: La Escasez de Agua en Varias Zonas del Mundo Amenaza la Seguridad Alimentaria y los Medios de Subsistencia. Available online: http://www.fao.org/news/story/es/item/283264/icode/ (accessed on 2 November 2017).

2. FAO. Escasez de Agua: Uno de Los Grandes Retos de Nuestro Tiempo. Available online: http://www.fao.org/zhc/detail-events/es/c/880888/ (accessed on 12 December 2017).

3. Eurostat. Agriculture, Forestry and Fishery Statistics. European Union, 2016. Available online: http://ec.europa.eu/eurostat/documents/3217494/7777899/KS-FK-16-001-EN-N.pdf/cae3c56f-53e2-404a9e9e-fb5f57ab49e3 (accessed on 10 November 2017).

4. MAPAMA. Encuesta Sobre Superficie y Rendimientos de Cultivos: Informe Sobre Regadíos en España. Ministry of Agriculture, Fishing and Environment of Spain. Available online: http://www.mapama.gob.es/es/estadistica/temas/estadisticas-agrarias/espana2017web_tcm7-474146.pdf (accessed on 8 January 2018).

5. Corominas, J. Agua y Energía en el riego en la época de la sostenibilidad. Ingeniería del Agua 2010, 17, 219233.

6. Pardo, M.A.; Manzano, J.; Cabrera, E.; García-Serra, J. Energy audit of irrigation networks. Biosyst. Eng. 2013, 115, 89-101.

7. IDAE. Protocolo de Auditoría Energética en Comunidades de Regantes; Ministerio de Industria, Turismo y Comercio: Madrid, Spain, 2008.

8. Blanco, M. Análisis de la Eficiencia Energética en el Uso del Agua de Riego. Graduation Thesis, University of Cordoba, Cordoba, Spain, June 2009.

9. Rodríguez Díaz, J.A.; Camacho Poyato, E.; LópezLuque, R.; Pérez Urrestarazu, L. Benchmarking and multivariate data analysis techniques for improving the efficiency of irrigation districts: an application in Spain. Agric. Syst. 2008, 96, 250-259.

10. Power, C.; Coughlan, P.; McNabola, A. The applicability of hydropower technology in waste water treatment plants. In Proceedings of the International Water Association World Congress on Water, Climate and Energy, Dublin, Ireland, 13-18 May 2012.

11. Corcoran, L.; Coughlan, P.; McNabola, A. Energy recovery potential using micro hydro power in water supply networks in the UK \& Ireland. Water Sci. Technol. 2013, 13, 552-560, doi:10.2166/ws.2013.050.

12. Ramos, S.; Gomes, A.; Cardoso, M.; Castanheira, L. Advantage of public water supply use for micro power generation. In Proceedings of the International Conference on Renewable Energy and Power Quality, Valencia, Spain, 15-17 April 2009.

13. Gallagher, J.; Harris, I.M.; Packwood, A.J.; McNabola, A.; Williams, A.P. A strategic assessment of microhydropower in the UK and Irish water industry: Identifying technical and economic constraints. Renew. Energy 2015, 81, 800-815, doi:10.1016/j.renene.2015.03.078.

14. Power, C.; McNabola, A.; Coughlan, P. Development of an evaluation method for hydropower energy recovery in wastewater treatment plants: Case studies in Ireland and the UK. Sustain. Energy Technol. Assess. 2014, 7, 166-177, doi:10.1016/j.seta.2014.06.001.

15. Power, C.; McNabola, A.; Coughlan, P. Micro-hydropower energy recovery at waste-water treatment plants: turbine selection and optimization. J. Energy Eng. 2016, 1, 143, doi:10.1061/(ASCE)EY.19437897.0000383.

16. Fecarotta, O.; Aricò, C.; Carravetta, A.; Martino, R.; Ramos, H.M. Hydropower potential in water distribution networks: Pressure control by PATs. Water Resour. Manag. 2015, 29, 699-714, doi:10.1007/s11269-014-0836-3.

17. Lydon, T.; Coughlan, P.; McNabola, A. Pump-as-turbine: Characterization as an energy recovery device for the water distribution network. J. Hydraul. Eng. 2017, 143, doi:10.1061/(ASCE)HY.1943-7900.0001316

18. Pérez-Sánchez, M.; Sánchez-Romero, F.J.; Ramos, H.M.; López-Jiménez, P.A. Modeling Irrigation Networks for the Quantification of Potential Recovering: A case study. Water 2016, 8, 234.

19. García Morillo, J.; Camacho, E.; Montesinos, P.; Rodríguez Díaz, J.A.; McNabola, A. Exploring hydro potential in a pressurized irrigation network. Hydroelectr. Dams 2017, 5, 66-73.

20. Clément, R. Calcul des débits dans les réseaux d'irrigation fonctionnant à la demande. La Houille blanche 1966, 5, 553-575.

21. Allen, R.G.; Pereira, L.S.; Raes, D.; Smith, M. Crop Evapotranspiration: Guidelines for Computing Crop Water Requirements; FAO Irrigation and Drainage Paper 56; FAO: Rome, Italy, 1998. 
22. Novara, D. Personal communication, 20 November 2017.

23. Carravetta, A.; del Giudice, G.; Fecarotta, O.; Ramos, H. Energy production in water distribution networks: a PAT design strategy. Water Res. Manag. 2012, 26, 3947-3959, doi:0.1007/s11269-012-0114-1.

24. Lydon, T. Innovation of a Micro-Hydropower Turbine to Recover Energy from Water Distribution Networks: Exploration of Design and Identification of Its Economic and Environmental Value. Ph.D. Thesis, Trinity College Dublin, Dublin, Ireland, September 2016.

(c)

(C) 2018 by the authors. Licensee MDPI, Basel, Switzerland. This article is an open access article distributed under the terms and conditions of the Creative Commons Attribution (CC BY) license (http://creativecommons.org/licenses/by/4.0/). 